\title{
The outcomes of controlled ovarian hyperstimulation/ intrauterine insemination in patients with unilateral tubal occlusion on hysterosalpingograph
}

\author{
Histerosalpingografide tek tarafl tubal oklüzyon saptanan \\ hastaların kontrollü ovaryan hiperstimulasyon/intrauterine \\ inseminasyon sonuçları
}

\author{
Selçuk Selçuk ${ }^{1}$, Mehmet Küçükbaş ${ }^{1}$, Ilter Yenidede ${ }^{2}$, Semra Kayataş Eser ${ }^{1}$, Ahmet Eser ${ }^{1}$, Çetin Çam ${ }^{1}$, \\ Hüseyin Tayfun Kutlu1
}

1Zeynep Kamil Women and Children's Diseases Education and Research Hospital, Clinics of Obstetrics and Gynecology, İstanbul, Turkey

${ }^{2}$ Fatih Sultan Mehmet Training and Research Hospital, Clinic of Obstetrics and Gynecology, İstanbul, Turkey

\begin{abstract}
Objective: The aim of the present study was to evaluate the pregnancy rates of intrauterine insemination (IUI) and controlled ovarian hyperstimulation $(\mathrm{COH})$ in patients with one-sided tubal occlusion on hysterosalpingography (HSG).

Materials and Methods: Patients who underwent COH/IUI were enrolled into this retrospective cohort study. The patients with one-sided tubal occlusion diagnosed under HSG who met the inclusion criteria were accepted into the study group. The control group consisted of patients with unexplained infertility. The outcomes of $\mathrm{COH} / \mathrm{IUI}$ were compared between the study and control groups.

Results: Ninety-seven patients in the study group $(n=44)$ and control group $(n=53)$ who underwent COH/IUI treatment were included into study. The biochemical, clinical, and ongoing pregnancy rates were similar between patients with unilateral occlusion diagnosed under HSG and those with unexplained infertility. The spontaneous pregnancy rate within one year was higher in patients with normal HSG than in patients with unilateral tubal occlusion, but the difference did not show statistical significance.

Conclusion: Infertile patients with one-sided tubal occlusion in HSG can be managed as with patients with unexplained infertility and normal HSG findings. In addition, $\mathrm{COH} / \mathrm{IUI}$ may be considered as the first-line treatment option in the management of these patients.
\end{abstract}

Keywords: Unilateral tubal occlusion, infertility, intrauterine insemination

$\ddot{\mathbf{O} z}$

Amaç: Bu çalışmada histerosalpingografide (HSG) tek taraflı tubal oklüzyon saptanmış olan hastaların kontrollü ovaryan hiperstimülasyon (KOH) ve intrauterine inseminasyon (IUI) tedavisi sonrası gebelik oranlarını araştırmayı amaçladık.

Gereç ve Yöntemler: Bu retrospektif kohort çalışmaya KOH/IUI tedavisi alan hastalar dahil edildi. HSG'de unilateral tubal oklüzyon saptanmış hastalar çalışma grubu olarak kabul edildi. Kontrol grubu; açıklanamayan infertilite tanısı almış hastalardan oluşturuldu. Çalışma ve kontrol grupları KOH/IUI sonuçları açısından karşılaştırıldı.

Bulgular: Bu çalışmaya KOH/IUI tedavisi almış 97 hasta (çalışma grubu=44, kontrol grubu=53) dahil edildi. HSG ile tanı konulmuş tek taraflı tubal oklüzyonu olan hastalar ile açıklanamayan infertilitesi olan hastalar arasında biyokimyasal, klinik ve devam eden gebelik oranları benzer olarak bulundu. Kontrol grubunda, ilk yl içinde spontan gebelik oranları çalışma grubuna göre daha yüksek olarak bulundu ancak bu fark istatistiksel olarak anlamlı değildi.

Sonuç: HSG'de tek taraflı tubal oklüzyon saptanan infertil hastalar, normal HSG bulgularına sahip infertil hastalar gibi yönetilebilirler. Ayrıca, belirtilen hasta grubunda $\mathrm{KOH} / \mathrm{IUI}$ ilk tedavi seçeneği olarak düşünülebilir.

Anahtar Kelimeler: Tek taraflı tubal oklüzyon, infertilite, intrauterin inseminasyon 


\section{Introduction}

Tubal disease is responsible for approximately 30-40\% of female infertility(1). Recently, the incidence of tubal factor has increased and has become a major cause of female infertility. The major risk factor for tubal factor infertility is pelvic inflammatory disease; other possible risk factors are history of tubal surgery and ectopic pregnancy (2). Hysterosalpingography (HSG) and laparoscopy are the most common procedures used in the assessment of the tubal patency. HSG is usually the first preferred clinical tool because laparoscopy is more invasive and more expensive(3). There is no consensus about the optimal management of patients with unilateral tubal occlusion. The assessment of tubal patency through laparoscopic chromotubation, intrauterine insemination with controlled ovarian stimulation $(\mathrm{COH})$, and in vitro fertilization (IVF) are the recommended management options for these patients(4-6). In the literature, there are insufficient data regarding the success rates of $\mathrm{COH}$ and IUI in the treatment of patients with unilateral tubal occlusion.

In the present study, we aimed to evaluate the pregnancy rates of $\mathrm{COH} / \mathrm{IUI}$ in patients with unilateral tubal occlusion diagnosed under HSG.

\section{Materials and Methods}

This retrospective cohort study was conducted in Zeynep Kamil Tertiary Hospital between 2013 and 2015. The study protocol was approved by the Local Research and Ethics Committee of the institution. Demographic and clinical information of patients were abstracted from the hospital's database. Inclusion criteria were age $\geq 18$ and $<40$ years, basal folliclestimulating hormone (FSH) level $<15 \mathrm{IU} / \mathrm{mL}$, normal basal luteinizing hormone, body mass index $<35 \mathrm{~kg} / \mathrm{m}^{2}$, normal semen parameters according to the World Health Organization (WHO) criteria, no presence of endocrine abnormalities, and no uterine cavity abnormalities(7). Patients with unilateral tubal occlusion diagnosed under HSG and who met the inclusion criteria were accepted into the study group. The control group consisted of patients with unexplained infertility, normal HSG findings and those who met the same inclusion criteria. All patients underwent $\mathrm{COH} / \mathrm{IUI}$ treatment.

In the ovarian stimulation protocol, subcutaneous injection of gonadotropins as recombinant FSH (Gonal F, Merck Serono, İstanbul, Turkey) with starting dose of 50-100 IU/day from the $2^{\text {nd }} 4$ th day of the menstrual cycle was administered. Monitoring using transvaginal ultrasonography (TVU) was performed daily after the fifth day of stimulus. When $\geq 2$ follicles reached a diameter of $\geq 17 \mathrm{~mm}$, subcutaneous injection of recombinant chorionic gonadotropin alpha $250 \mathrm{mg}$ (Ovitrelle; MerckSerono, İstanbul, Turkey) was administered. A concentrated, washed sperm sample was prepared and IUI was performed 3436 hours after human chorionic gonadotropin (hCG) injection. Primary outcomes were biochemical, clinical, and ongoing pregnancy rates. The secondary outcome was the spontaneous pregnancy rate. Patients were invited to the infertility clinic to measure the $\beta$-hCG value 15 days after IUI. Positive serum $\beta$-hCG levels as $\geq 10 \mathrm{mIU} / \mathrm{L}$ were regarded as biochemical pregnancy and presence of a gestational sac on ultrasonography was regarded as clinical pregnancy. Ongoing pregnancy was defined as a pregnancy $\geq 12$ weeks of gestation. Spontaneous pregnancy was accepted as pregnancy without any treatment within one year after unsuccessful IUI.

\section{Statistical Analysis}

Statistical analysis was performed using SPSS version 15.0 software. Mann-Whitney U test and Pearson's Chi-square tests were performed where appropriate. A value of $\mathrm{p}=0.05$ was accepted as the degree of significance. Data are given as mean \pm standard deviation or percentage.

\section{Results}

Ninety-seven patients who met the inclusion criteria and underwent $\mathrm{COH} / \mathrm{IUI}$ treatment were included in study. Fortyfour patients with unilateral tubal occlusion were included into the study group and 53 patients with unexplained infertility were assigned as the control group. Comparison of baseline clinical characteristics and sperm parameters of the two groups are given in Table 1. There were no significant differences between the study and control groups. In addition, there were no significant differences regarding IUI cycle characteristics of patients when the two groups were compared (Table 1). The biochemical, clinical, and ongoing pregnancy rates of the two groups are given in Table 2. The biochemical, clinical, and ongoing pregnancy rates per cycle of study group were $13.6 \%$, $11.4 \%$, and $11.4 \%$, respectively. The biochemical, clinical, and ongoing pregnancy rates of the control group were $9.4 \%$ for all parameters. There were no statistical differences between the two groups. The spontaneous pregnancy rates were found $15.9 \%$ and $18.9 \%$ for study group and control group, respectively, and there was no statistically significant difference.

\section{Discussion}

In present study, the biochemical, clinical, and ongoing pregnancy rates of $\mathrm{COH} / \mathrm{IUI}$ treatment were similar between patients with unilateral occlusion and patients with unexplained infertility. In addition, the spontaneous pregnancy rate within one year after unsuccessful IUI treatment was higher in the control group than in the study group but the difference did not reach statistical significance.

The management of infertile patients showed differences based on their HSG findings. In general, patients with bilateral tubal occlusion can be referred to IVF treatment or for further evaluation for tubal patency with laparoscopic chromotubation. The management of patients with one-sided tubal occlusion is less clear $(1,8)$

In the literature, the diagnostic accuracy of HSG was evaluated in various studies. Mol et al. (9) conducted a prospective cohort study of 794 patients with the participation of 11 clinics 
to evaluate the importance of HSG and laparoscopy for the prediction of fertility outcomes. The sensitivity and specificity of HSG was reported as 0.81 and 0.75 , respectively, for any form of tubal occlusion at laparoscopic surgery.

The authors reported the adjusted fecundity rate ratios (FRR) for unilateral tubal occlusion diagnosed at HSG as 0.80 and for bilateral tubal occlusion as 0.49. Accordingly, the authors concluded that bilateral tubal occlusion significantly impaired fertility outcomes whereas unilateral tubal occlusion mildly reduced fertility outcomes. Diagnosis of occlusion at laparoscopy had a greater worsening effect on fertility outcomes (FRR $=0.51$ and 0.15 for unilateral and bilateral tubal occlusion, respectively) than those at $\mathrm{HSG}^{(9)}$.

A retrospective study assessed the fertility prognosis of patients with tubal occlusion detected using HSG. The FRR of unilateral tubal occlusion was 0.81 and that of bilateral tubal occlusion

Table 1. Comparison of demographic and clinical characteristics between the two groups

\begin{tabular}{|c|c|c|c|}
\hline & $\begin{array}{l}\text { Study group } \\
(\mathrm{n}=44)(\text { mean } \\
\pm \text { SD) }\end{array}$ & $\begin{array}{l}\text { Control group } \\
(\mathrm{n}=53)(\text { mean } \\
\pm \text { SD) }\end{array}$ & $\mathrm{p}$ \\
\hline Age (years) & $30.09 \pm 3.92$ & $28.49 \pm 4.45$ & NS \\
\hline Gravida & $0.36 \pm 1.16$ & $0.23 \pm 0.75$ & NS \\
\hline $\begin{array}{l}\text { Duration of infertility } \\
\text { (years) }\end{array}$ & $3.73 \pm 1.95$ & $3.88 \pm 2.80$ & NS \\
\hline Infertility type (\%) & & & NS \\
\hline Primary & 90.9 & 90.6 & \\
\hline Secondary & 9.1 & 9.4 & \\
\hline Basal FSH (mIU/mL) & $7.34 \pm 1.96$ & $7.27 \pm 1.75$ & NS \\
\hline Basal E2 (pg/mL) & $53.28 \pm 24.11$ & $52.17 \pm 27.60$ & NS \\
\hline $\begin{array}{l}\text { Basal sperm } \\
\text { concentration }\left(10^{6} / \mathrm{mL}\right)\end{array}$ & $50.05 \pm 31.68$ & $60.1 \pm 31.02$ & NS \\
\hline $\begin{array}{l}\text { Basal total sperm count } \\
\left(10^{6}\right)\end{array}$ & $166.15 \pm 149.92$ & $187.89 \pm 150.87$ & NS \\
\hline $\begin{array}{l}\text { Basal total sperm } \\
\text { motility (\%) }\end{array}$ & $60.84 \pm 13.75$ & $58.04 \pm 16.60$ & NS \\
\hline $\begin{array}{l}\text { Previous IUI cycles } \\
\text { (no) }\end{array}$ & $0.36 \pm 0.57$ & $0.28 \pm 0.82$ & NS \\
\hline $\begin{array}{l}\text { Duration of stimulation } \\
\text { (days) }\end{array}$ & $8.43 \pm 2.78$ & $7.82 \pm 2.41$ & NS \\
\hline $\begin{array}{l}\text { Total gonadotropine } \\
\text { dose (IUI) }\end{array}$ & $609.89 \pm 293.06$ & $585.58 \pm 178.94$ & NS \\
\hline No of dominant follicle & $1.25 \pm 0.44$ & $1.16 \pm 0.37$ & NS \\
\hline EL on hCG day (mm) & $9.47 \pm 2.36$ & $7.90 \pm 1.59$ & NS \\
\hline \multicolumn{4}{|c|}{$\begin{array}{l}\text { The level of significance was accepted at } \mathrm{p}=0.05 \text { level, Data were given as mean } \pm \text { SD } \\
\text { and (\%), FSH: Follicle stimulating hormone, EL: End line, No: Number, IUI: Intrauterine } \\
\text { insemination, hCG: Human chorionic gonadotropin, SD: Standard deviation, NS: Not } \\
\text { significant, E2: Estradiol }\end{array}$} \\
\hline
\end{tabular}

was $0.30(10)$. The authors suggested that patients with onesided tubal pathology and patients with normal HSG findings had nearly similar fertility potential, but the presence of bilateral tubal pathology detected on HSG decreased fertility potential significantly. In our study, the spontaneous pregnancy rate of patients with normal HSG findings was higher than patients with one-sided tubal occlusion, but the difference was not found as statistically significant ( $18.9 \%$ vs. $15.9 \%, \mathrm{p}>0.05$ ). In the literature, the success rates of $\mathrm{COH} / \mathrm{IUI}$ in patients with diagnosis of unilateral tubal occlusion at HSG were assessed in different studies. In a retrospective study, Lin et al.(2) reported that the pregnancy rates per cycle of $\mathrm{COH} / \mathrm{IUI}$ treatment for patients with one-sided tubal occlusion on HSG and those with normal HSG findings were $17.3 \%$ and $18.9 \%$, respectively. The difference of pregnancy rates between the two groups showed no statistical significance. The authors stated that $\mathrm{COH} / \mathrm{IUI}$ could be initial treatment options for infertile patients with unilateral tubal occlusion. Farhi et al.(11) assessed the cumulative pregnancy rates for three cycles of $\mathrm{COH} / \mathrm{IUI}$ treatment among patients diagnosed as having one-sided tubal occlusion compared with patients with unexplained infertility (controls). The cumulative pregnancy rates were reported as $30.9 \%$ for the study group and $42.6 \%$ for the control group. The authors stated that there was no significant difference between the two groups in terms of cumulative pregnancy rates. Yi et al.(12) evaluated the outcomes of $\mathrm{COH} / \mathrm{IUI}$ treatment among thirty-seven infertile women (52 cycles) with unilateral tubal occlusion compared with a control group that included patients with unexplained infertility. The pregnancy rate per cycle was $17.3 \%$ in patients with unilateral tubal occlusion and $16.5 \%$ in the control group without statistical significance. The outcomes

Table 2. Comparison of outcomes of intrauterine insemination cycles between two groups

\begin{tabular}{|c|c|c|}
\hline & $\begin{array}{l}\text { Study group } \\
(\mathrm{n}=44)\end{array}$ & $\begin{array}{l}\text { Control group } \\
(n=53)\end{array}$ \\
\hline Biochemical pregnancy rate & & \\
\hline
\end{tabular}
(n)
(6)
(5)

Clinical pregnancy rate

$\begin{array}{llll}\% & 11.4 & 9.4 & \text { NS }\end{array}$
(n)
(5)
(5)

Ongoing pregnancy rate

$\begin{array}{llll}\% & 11.4 & 9.4 & \text { NS } \\ \text { (n) } & (5) & (5) & \end{array}$

Spontaneous pregnancy rate

$\begin{array}{llll}\% & 15.9 & 18.9 & \text { NS }\end{array}$

(n)

(7)

(10)

The level of significance was accepted at $\mathrm{p}=0.05$ level, Chi-square test was used, NS: Not significant 
of our study are similar with the literature. In the present study, the ongoing pregnancy rate per cycle of study group was $11.4 \%$ whereas the ongoing pregnancy rate per cycle of control group was $9.4 \%$. The biochemical, clinical, and ongoing pregnancy rates per cycles did not show a significant difference between the study and control groups.

Conflicting results about the clinical importance of the site of tubal occlusion and outcomes of COH/IUI treatment are reported in different studies. Lower pregnancy rates are demonstrated in women with mid-distal or distal tubal occlusion than in women with proximal tubal occlusion $(2,11,12)$. Some authors stated that the site of tubal occlusion should be considered in the management of patients with unilateral tubal occlusion whereas others reported that the site of tubal occlusion had no importance in the management of these patients $(2,11,12)$.

The relatively small sample size and retrospective nature of the study were the limitations of the present study.

\section{Conclusion}

Infertile patients with one-sided tubal occlusion on HSG can be managed as with patients with unexplained infertility and normal findings on HSG. In addition, COH/IUI may be considered as the first-line treatment option in the management of these patients.

\section{Ethics}

Ethics Committee Approval: The study protocol was approved by the Local Research and Ethics Committee of the institution, Informed Consent: This retrospective cohort study was conducted in Zeynep Kamil Tertiary Hospital between 2013 and 2015.

Peer-review: External and Internal peer-reviwed.

\section{Authorship Contributions}

Surgical and Medical Practices: Hüseyin Tayfun Kutlu, Concept: Selçuk Selçuk, Çetin Çam, Design: Selçuk Selçuk, Semra Kayataş Eser, Data Collection or Processing: Ilter Yenidede, Mehmet Küçükbaş, Analysis or Interpretation: Çetin Çam, Literature Search: Ahmet Eser, Semra Kayataş Eser, Writing: Selçuk Selçuk, Hüseyin Tayfun Kutlu.

Conflict of Interest: No conflict of interest was declared by the authors.
Financial Disclosure: The authors declared that this study received no financial support

\section{References}

1. Lavy Y, Lev-Sagie A, Holtzer H, Revel A, Hurwitz A. Should laparoscopy be a mandatory component of the infertility evaluation in infertile women with normal hysterosalpingogram or suspected unilateral distal tubal pathology? Eur J Obstet Gynecol Reprod Biol 2004;114:64-8.

2. Lin MH, Hwu YM, Lin SY, Lee RK. Treatment of infertile women with unilateral tubal occlusion by intrauterine insemination and ovarian stimulation. Taiwan J Obstet Gynecol 2013;52:360-4.

3. Balasch J. Investigation of the infertile couple in the era of assisted reproductive technology: A time for reappraisal. Hum Reprod 2000;15:2251-7.

4. Fergusson ILC. Laparoscopic investigation of tubal infertility. Tubal infertility, diagnosis, and treatment. Oxford: Blackwell; 1982. p. 3046.

5. Ebrahimi M, Akbari Asbagh F, Ghaseminejad A. Controlled ovarian hyperstimulation and intrauterine insemination cycles in patients with unilateral tubal blockage diagnosed by hysterosalpingography. Iran J Reprod Med 2011;9:15-20.

6. Berker B, Şükür YE, Kahraman K, Atabekoğlu CS, Sönmezer M, Özmen B, et al. Impact of unilateral tubal blockage diagnosed by hysterosalpingography on the success rate of treatment with controlled ovarian stimulation and intrauterine insemination. J Obstet Gynaecol 2014;34:127-30.

7. World Health Organization. Laboratory manual for the examination of human semen and semen-cervical mucus interaction. 3rd ed. New York: Cambridge University Press; 1993.

8. Mol BW, Swart P, Bossuyt PM, van der Veen F. Prognostic significance of diagnostic laparoscopy for spontaneous fertility. J Reprod Med 1999;44:8-6.

9. Mol BW, Collins JA, Burrows EA, van der Veen F, Bossuyt PM. Comparison of hysterosalpingography and laparoscopy in predicting fertility outcome. Hum Reprod 1999;14:1237-42.

10. Mol BW, Swart P, Bossuyt PM, van der Veen F. Is hysterosalpingography an important tool in predicting fertility outcome? Fertil Steril 1997;67:663-9.

11. Farhi J, Ben-Haroush A, Lande Y, Fisch B. Role of treatment with ovarian stimulation and intrauterine insemination in women with unilateral tubal occlusion diagnosed by hysterosalpingography. Fertil Steril 2007;88:396-400.

12. Yi G, Jee BC, Suh CS, Kim SH. Stimulated intrauterine insemination in women with unilateral tubal occlusion. Clin Exp Reprod Med 2012;39:68-72. 